\title{
ANALISIS DIKABULKANNYA PERMOHONAN PENINJAUAN KEMBALI SETELAH PELAKSANAAN PUTUSAN SENGKETA GADAI TANAH ULAYAT*
}

\author{
Aulia Ade Putra \\ Fakultas Hukum, Universitas Andalas \\ Kampus Limau Manis Padang, Provinsi Sumatera Barat, Indonesia \\ e-mail: auliaade.putra90@gmail.com
}

\begin{abstract}
The settlement of agricultural land plot disputes over communal ulayat often culminates in the settlement in the realm of the Court. The judge's ruling is based on Law Number 56 Prp of 1960 and there are decisions based on Minangkabau Traditional Law. The problem was how the consideration of the panel of judges on the settlement of agricultural land disputes over ulayat of the people in the decision of Review of number 394 PK/PD/2011 and How the position of the land buyer in the settlement of agricultural land disputes disputes over ulayat people after the release of judgment review number 394 PK/PDT/2011. The method used to solve the problem was normative juridical, meaning that by using the approach of legislation and relevant theory will illustrate the legal certainty relating to the problems that have been formulated. The result of the research which was derived from the problem formulation was obtained the result, the settlement of agricultural land disputes over the ulayat of the people in the court should be based on the National Legislation and the Minangkabau Adat Law provisions, the two legal bases are contradicted and in the decision of Review Number 394 PK/PDT/2011, the Panel of Judges of Judicial Review did not base the judgment of the Review on the National Law and Minangkabau Customary Law and the possession of the object was submitted to the purchaser of the object of such pledge. The judge's opinion on this Review was false, unfounded and not fair because it was inconsistent with the National Law and Minangkabau Law.
\end{abstract}

Keywords: Agricultural Land Pest; Disputes; Review; Ulayat Community.

\begin{abstract}
Abstrak
Penyelesaian sengketa gadai tanah pertanian atas ulayat kaum seringkali berujung pada penyelesaian di ranah Pengadilan. Putusan Hakim ada yang didasarkan pada Undang-Undang Nomor 56 Prp Tahun 1960 dan ada putusan didasarkan pada ketentuan Hukum Adat Minangkabau. Permasalahannya Bagaimana pertimbangan majelis hakim terhadap penyelesaian sengketa gadai tanah pertanian atas ulayat kaum dalam putusan Peninjauan Kembali nomor 394 PK/ PDT/ 2011 dan Bagaimana kedudukan pembeli tanah perkara dalam penyelesaian sengketa gadai tanah pertanian atas ulayat kaum setelah keluarnya putusan peninjauan kembali nomor 394 PK/ PDT/ 2011. Metode yang digunakan memecahkan permasalahan adalah yuridis normatif, dengan menggunakan pendekatan peraturan perundang-undangan dan teori yang relevan akan menggambarkan kepastian hukum yang berkaitan dengan permasalahan yang dirumuskan. Hasil penelitian beranjak dari rumusan masalah diperoleh hasil, penyelesaian sengketa gadai tanah pertanian atas ulayat kaum di pengadilan seharusnya didasarkan pada Perundang-Undangan Nasional dan ketentuan Hukum Adat Minangkabau, dasar hukum tersebut mengalami pertentangan. Pada Putusan Peninjauan Kembali Nomor 394 PK/PDT/2011, Majelis Hakim Peninjauan Kembali tidak mendasarkan putusan Peninjauan Kembali pada Hukum Nasional dan Hukum Adat Minangkabau dan penguasaan objek perkara diserahkan kepada pembeli objek gadai. Pendapat hakim Peninjauan Kembali sangatlah keliru, tidak berdasar dan jauh dari keadilan karena tidak sesuai dengan Hukum Nasional dan Hukum Adat Minangkabau.
\end{abstract}

Kata Kunci: Gadai Tanah Pertanian; Peninjauan Kembali; Sengketa; Ulayat Kaum.

\footnotetext{
* Naskah diterima: 16 Oktober 2018, direvisi: 07 Maret 2019, disetujui untuk terbit: 19 Maret 2019 Doi: $\underline{10.3376 / \text { jch.v4i2.101 }}$
} 


\section{PENDAHULUAN}

Hal-hal mendasar berkaitan dengan hubungan manusia dengan tanah dapat berupa faktor manusia yang bersifat individu maupun kelompok, dalam bentuk badan usaha, instansi pemerintah, dan negara. Dari masing-masing profil manusia tersebut memiliki ideologi dan kepentingan yang berbeda dalam memandang tanah yang dipengaruhi oleh ruang dan waktu. Pada sekelompok masyarakat tradisional (contohnya dalam bentuk masyarakat adat) memiliki konsep hubungan dengan tanah yang amat sederhana, dalam arti mereka memiliki hubungan tanah dalam kaitan dengan kehidupan sehari-hari, dalam kaitan pangan (makanan), sandang (pakaian), dan papan (tempat tinggal). Sementara pada jenis kelompok manusia lainnya dalam bentuk badan usaha, memandang tanah dan memaknai hubungan mereka dengan tanah sebagai faktor produksi yang menjadi target eksploitasi menurut hukum-hukum ekonomi yang mereka jalankan, seperti prinsip umum "pengorbanan yang sekecil-kecilnya namun memperoleh keuntungan yang sebesar-besarnya (Suparjo Sujadi, 2004: $365)$.

Gadai tanah atas ulayat kaum masih banyak dilakukan di tengah Masyarakat Hukum Adat Minangkabau karena sifatnya cepat dan mudah. Permasalahan kembali ke pemilik tanpa tebusan untuk gadai tanah pertanian ini di Sumatera Barat yang sebagian besar tunduk pada Hukum Adat Minangkabau juga menimbulkan persoalan tersendiri.
Gadai tanah adalah merupakan pranata yang muncul dari realisasi kehidupan sosial yang mengandung nilai hukum dan akan tetapi berada dalam kehidupan manusia yang menggunakannya (Muhammad Yamin, 2004: 66).

Menurut Iman Sudiyat gadai tanah adalah "Penyerahan tanah untuk menerima pembayaran sejumlah uang secara tunai dengan ketentuan: sipenjual tetap berhak atas pengembalian tanahnya dengan jalan menebusnya kembali (Iman Sudiyat, 2012: 28).

Menurut Boedi Harsono gadai tanah adalah "Hubungan hukum antara seseorang dengan tanah kepunyaan orang lain, yang telah menerima uang gadai dari padanya. Selama uang gadai belum dikembalikan, tanah tersebut dikuasai oleh "Pemegang Gadai". Selama itu hak tanah seluruhnya menjadi hak pemegang gadai. Pengembalian uang gadai atau yang lazim disebut "Penebusan", tergantung pada kemauan dan kemampuan pemilik tanah yang menggadaikan. Banyak gadai yang berlangsung bertahun-tahun, bahkan sampai puluhan tahun karena pemilik tanah belum mampu melakukan penebusan (Boedi Harsono, 2007: 394).

Dalam hukum adat Minangkabau dikenal pepatah "Gadai ditabuih, jua dipalalui" (gadai harus ditebus, jual dibiarkan lepas). Gadai di Minangkabau selalu ditebusi, tanpa terikat pada suatu jangka waktu tertentu. Gadai harus ditebus kembali sedangkan dalam jual beli lepas begitu saja tidak ada batas 
Aulia Ade Putra: Analisis Dikabulkannya Permohonan Peninjauan Kembali...

waktunya. Dalam hal ini pengembalian gadai yang tanpa tebusan tentu menimbulkan persoalan hukum.

Sengketa adalah pertentangan antara dua pihak atau lebih yang berawal dari persepsi yang berbeda tentang suatu kepentingan atau hak milik yang dapat menimbulkan akibat hukum bagi keduanya. (Takdir Rahmadi, 2010: 1)

Sehubungan dengan sengketa berkenaan dengan pengembalian gadai tanpa tebusan ini putusan Pengadilan sendiri terhadap kasus ini tidaklah sama. Di beberapa Pengadilan tidak selalu menerapkan ketentuan Pasal 7 UndangUndang Nomor 56 Prp Tahun 1960, yakni mengakomodir ketentuan bahwa setelah lewat jangka waktu 7 tahun gadai tanah pertanian harus dikembalikan kepada sipemilik oleh Pemegang Gadai tanpa menerima uang tebusan. Namun ada juga kasus yang putusan Pengadilan justru bertentangan dengan ketentuan hukum positif ini dan mengakomodir ketentuan Hukum Adat Minangkabau bahwa pengembalian gadai harus melalui penyerahan uang tebusan oleh pemilik kepada Pemegang Gadai.

Dalam kasus sengketa gadai tanah pertanian atas ulayat kaum ini, putusan pada setiap tingkat Pengadilan diterapkan berbeda-beda, ada yang menerapkan implementasi ketentuan Pasal 7 UndangUndang Nomor 56 Prp Tahun 1960 dan ada juga menerapkan ketentuan hukum adat minangkabau yang akan diuraikan sebagai berikut:
1. Putusan Pengadilan Negeri Solok atas perkara Nomor : 05/Pdt.G/2003/PN.SLK tanggal 20 April 2004, yang memutuskan perkara berdasarkan atau sesuai dengan Pasal 7 Undang-Undang Nomor 56 Prp Tahun 1960 bahwa gadai tanah pertanian dikembalikan setelah lewat jangka waktu 7 tahun tanpa uang tebusan. Namun putusan ini dibatalkan ditingkat Banding oleh Pengadilan Tinggi.

2. Putusan pada Pengadilan Tinggi Padang Nomor : 108/PDT/2004/PT.PDG tanggal 08 Oktober 2004 yang memutuskan perkara tidak mengikuti ketentuan Pasal 7 Undang-Undang Nomor 56 Prp Tahun 1960 bahwa gadai tanah pertanian dikembalikan setelah lewat jangka waktu 7 (tujuh) tahun tanpa uang tebusan. Dimana dalam putusan ini pengembalian tanah gadai tetap harus dilakukan dengan uang tebusan dan Putusan ini dibatalkan di tingkat upaya hukum Kasasi oleh Mahkamah Agung.

3. Putusan Mahkamah Agung Nomor: 1540 K/Pdt/2005 tanggal 19 Juni 2006 yang memutus perkara dengan menerima gugatan penggugat terhadap objek perkara berupa sawah yang telah tergadai lebih dari 7 tahun dan dikuasai kembali oleh penggugat tanpa tebusan. Artinya Mahkamah Agung pada tingkat kasasi mengakomodir ketentuan Pasal 7 Undang-Undang Nomor 56 Prp Tahun 1960 bahwa gadai tanah pertanian dikembalikan setelah lewat jangka waktu 7 tahun tanpa uang tebusan. Namun pada 
tingkat upaya hukum Peninjauan

Kembali putusan ini dibatalkan.

Dari putusan-putusan ini dapat dilihat adanya persoalan hukum seputar pengembalian gadai tanpa tebusan yang merujuk pada ketentuan pasal 7 UndangUndang Nomor 56 Prp Tahun 1960. Ketentuan ini tidak disikapi sama pada setiap tingkat Peradilan dengan putusan yang tidak selalu sama dalam kasus yang sama.

Dari putusan ini bisa dilihat Pengadilan Negeri Solok dan upaya hukum Kasasi di Mahkamah Agung lah yang konsisten terhadap Undang-Undang Nomor 56 Prp Tahun 1960. pada tingkat Pengadilan Tinggi lebih mengacu kepada ketentuan Hukum Adat Minangkabau bahwa dalam pelaksanaan gadai tanah pertanian berpedoman kepada Hukum Adat Minangkabau yang dikenal dengan pepatah "Gadai ditabuih, jua dipalalui", (gadai harus ditebus, jual dibiarkan lepas), artinya Pengadilan Tinggi menerapkan bahwa setiap gadai tanah pertanian baru akan berakhir dengan adanya penebusan. Tiada gadai yang bisa selesai tanpa ditebus. Sedangkan sikap Mahkamah Agung melalui putusan Kasasinya menerapkan ketentuan Pasal 7 UndangUndang Nomor 56 Prp Tahun 1960 gadai kembali tanpa tebusan, Putusan Mahkamah Agung yang telah berkekuatan hukum tetap tersebut (Inkracht Van Gewijsde) tidaklah konsisten, putusan tersebut dibatalkan oleh Mahkmah Agung sendiri melalui Putusan Hakim Peninjauan Kembali Mahkamah Agung Republik Indonesia Nomor: 394
PK/PDT/2011 yang dalam amar putusannya menyatakan walaupun Hukum Adat Minangkabau mengenal konsep "gadai batabuih" yang artinya tanah yang digadaikan baru dapat dikuasai kembali oleh si pemilik membayar utangnya kepada pemegang gadai, namun Hukum Nasional Pasal 7 ayat (1) Undang-Undang Nomor 56 Prp Tahun 1960 telah tegas menyatakan tanah gadai harus dikembalikan kepada pemilik asal setelah 7 (tujuh) tahun perjanjian gadai.

Dari beberapa putusan ini dapat dilihat bahwa ketentuan Pasal 7 UndangUndang Nomor 56 Prp Tahun 1960 merupakan hukum positif yang berlaku di Indonesia karena belum pernah dicabut pemberlakuannya, namun dalam penerapannya terutama dalam hal penyelesaian sengketa yang timbul disebabkan oleh ketentuan tersebut oleh hakim di setiap tingkat pengadilan berbeda-beda atau tidaklah sama.

Menurut ajaran adat Minangkabau pengertian antara tanah dan ulayat dipisahkan. Dalam konsep hukum adat, tanah adalah empunya manusia dan manusia adalah empunya bumi/tanah, karena hubungan antara manusia dengan tanah/bumi mempunyai hubungan yang tidak dapat dipisahkan, keduanya adalah tunggal dan bersifat abadi (Dominikus Rato, 2016: 5).

Dalam praktik gadai tanah ulayat kaum Masyarakat Minangkabau tidak bisa dihindarkan dari benturan sengketa tanah ulayat, dimana perselisihan hukum atas tanah ulayat antara dua pihak yang 
Aulia Ade Putra: Analisis Dikabulkannya Permohonan Peninjauan Kembali...

bersengketa yaitu penguasa dan atau pemilik tanah ulayat dengan pihak lain. Azas utama tanah ulayat bersifat tetap berdasarkan filosofi adat Minangkabau "jua indak di makan bali, gadai indak dimakan sando". Hukum adat Minangkabau mengatur hal-hal yang berkaitan dengan tanah ulayat dengan maksud melindungi tanah ulayat sekaligus masyarakat hukum adat dapat memanfaatkan sumber daya alam yang terdapat di dalamnya dan tanah ulayat ini diharapkan dapat menjadi penopang kelangsungan hidup secara berkelanjutan dari generasi ke generasi berikutnya dan tidak terputus antar generasi dalam masyarakat hukum adat.

Tanah ulayat di Minangkabau lazim dikenal dengan istilah Pusako Tinggi karena kepemilikan asal tanah ini sudah sulit ditelusuri historisnya atau dengan arti kata sudah tidak dikenal lagi. Menurut adat untuk memanfaatkan tanah pusako tinggi berlaku 4 asas yaitu: (Musyair Zainuddin, 2014: 92)

1. Asas terpisah;

2. Asas komunal;

3. Asas keutamaan;

4. Asas unilateral.

Berdasarkan Pasal 12 ayat

Peraturan Daerah Propinsi Sumatera Barat Nomor: 16 Tahun 2008 tentang Tanah Ulayat Dan Pemanfaatannya "sengketa tanah ulayat di Nagari diselesaikan oleh KAN menurut ketentuan sepanjang adat yang berlaku "bajanjang naiak batanggo turun" dan diusahakan dengan jalan perdamaian melalui musyawarah dan mufakat dalam bentuk keputusan perdamaian. Selanjutnya pada ayat (2) menyebutkan "apabila keputusan perdamaian tidak diterima oleh pihak yang bersengketa dapat mengajukan perkaranya ke Pengadilan Negeri”. Khusus untuk sengketa tanah ulayat antar Nagari juga telah diatur dalam peraturan ini, dimana diselesaikan oleh KAN antar Nagari yang bersengketa.

Kelembagaan peradilan adat yang dimaksud bukanlah peradilan adat seperti yang berlangsung pada masa penjajahan Belanda, tetapi penyelesaian sengketa adat di luar peradilan litigasi. Keberadaan peradilan adat ini walaupun tidak diakui dalam Undang-Undang Kekuasaan Kehakiman, namun secara hukum penyelesaian sengketa seperti ini juga telah mendapat penguatan dari UndangUndang Nomor 30 Tahun 1999 (Lembaran Negara Republik Indonesia Tahun 1999 Nomor 138) tentang Arbitrase dan Alternatif Penyelesaian Sengketa yakinnya penyelesaian melalui peradilan adat dijalankan oleh Kerapatan Adat Nagari (KAN). Namun penyelesaian ini juga dilakukan bertingkat mulai dari penyelesaian dari "kerapatan jurai", "Kerapatan Kaum", "Kerapatan Suku" hingga akhirnya sampai pada Kerapatan Adat Nagari (Kurnia Warman, 2009: 299).

Menurut Undang-Undang Nomor 56 Prp Tahun 1960 (Lembaran Negara Tahun 1960 Nomor 174720) tentang penetapan Luas Tanah Pertanian dalam Pasal 7 ayat (2) menyebutkan bahwa gadai tanah pertanian adalah hubungan seseorang dengan tanah kepunyaan orang 
lain yang mempunyai utang kepadanya. Selama utang tersebut belum dibayar lunas, maka tanah tersebut tetap berada dalam penguasaan yang meminjamkan uang (pemegang gadai). Namun apabila telah lewat jangka waktu 7 (tujuh) tahun maka pengembalian tanah tersebut tanpa uang tebusan. Dalam hal ini khusus untuk tanah pertanian. Hal ini karena selama itu hasil tanah seluruh panennya menjadi hak pemegang gadai, yang dengan demikian merupakan bunga dari utang tersebut (Aermadepa, 2018 : 4).

Menurut ketentuan adat harta pusaka tinggi harus dipelihara, dan tidak mungkin dilakukan transaksi pelepasan hak kepemilikan bersama oleh siapapun. Pelepasan hak atas tanah pusaka hanya dapat ditempuh dalam keadaan yang sangat mendesak dan mendapat persetujuan dari seluruh anggota keluarga yang berhak terhadap harta pusaka itu, sebagaimana dinyatakan dalam pepatah adat sebagai berikut; (Erwin, 2006: 145)

1. Rumah gadang katirisan (Rumah besar kebocoran) maksudnya gadai dapat dilakukan untuk memperbaiki rumah yang telah bocor atau rusak. (Memperbaiki rumah gadang);

2. Gadih gadang indak balaki (Gadis yang sudah dewasa yang belum bersuami atau janda yang mendapat malu) maksudnya untuk mengawinkan kemenakan yang telah dewasa atau janda. (Biaya perkawinan anak perempuan);

3. Mayat tabujuah di ateh rumah (Mayat terbujur di tengah rumah) maksudnya gadai dapat dilakukan untuk menyelenggarakan penguburan mayat anggota kaum yang meninggal. (Biaya penguburan);

4. Mambangkik batang tarandam (membangkit batang terendam) maksudnya gadai dapat dilakukan untuk menutup malu keluarga atau kaum. (Biaya pengangkatan penghulu).

Kalau tidak karena hal tersebut diatas sekali-sekali tidak boleh sawah ladang digadaikan atau dijual. Sekali-sekali tidak boleh sawah ladang itu dijadikan perdagangan. Kalau terjadi pegang gadai itu adalah sifat sosial (tolong-menolong) untuk mengatasi kesulitan-kesulitan yang tersebut diatas, sehingga di sini tidak ada unsur pemerasan. Gadai di Minangkabau selalu ditebusi, tanpa terikat pada suatu jangka waktu tertentu. Hal ini sesuai dengan ketentuan adat yang berbunyi "Gadai ditabui, jua dipalalui" (gadai ditebus, jual dibiarkan berlalu) yang "artinya gadai harus ditebus kembali sedangkan dalam jual beli lepas begitu saja tidak ada batas waktunya". Jadi dapat terlihat gadai tanah di Minangkabau tidak selalu terkait dengan perbuatan hukum utang piutang yang diikuti dengan pemberian jaminan.

Pelaksanaan gadai tanah yang didasarkan pada hukum adat seringkali berujung pada sengketa yang penyelesaiannya pada ranah Pengadilan dan pada proses penyelesaian tingkat Pengadilan Negeri seringkali menimbulkan dua pandangan terkait dengan gadai tanah pertanian atas ulayat kaum ini, pandangan yang pertama mengacu pada Pasal 7 Undang-Undang 
Aulia Ade Putra: Analisis Dikabulkannya Permohonan Peninjauan Kembali...

Nomor 56 Prp Tahun 1960 (Lembaran Negara Tahun 1960 Nomor 174720), dapat diartikan "gadai tanah pertanian apabila sudah berlangsung 7 tahun atau lebih wajib mengembalikan tanah tersebut kepada pemiliknya dalam waktu sebulan setelah tanam yang ada selesai dipanen, dengan tidak ada hak untuk menuntut pembayaran uang tebusan" dan pandangan kedua mengacu kepada ketentuan Hukum Adat Minangkabau dimana pengembalian gadai harus melalui penyerahan uang tebusan dan terhadap pandangan kedua ini tanah objek gadai yang dikuasai pemegang gadai baru dapat dikembalikan kepada pemberi gadai setelah adanya upaya penyerahan sejumlah uang (penebusan).

Dari 2 (dua) pandangan tersebut putusan-putusan penyelesaian sengketa gadai tanah atas ulayat kaum melalui Pengadilan Negeri menimbulkan persoalan hukum yang berakibat ketidakpastian hukum yang harus dicarikan solusinya, dimana terhadap kasus yang sama, putusan Pengadilan Negeri dapat berbeda-beda, bisa mengacu pada Undang-Undang Nomor 56 Prp Tahun 1960 atau ketentuan hukum adat Minangkabau dan terhadap ketentuan Pasal 7 Undang-Undang Nomor 56 Prp Tahun 1960 Tentang Penetapan Luas Tanah Pertanian tersebut sampai saat sekarang ini masih tetap berlaku dan belum pernah diganti ataupun dicabut.

Penyelesaian sengketa gadai tanah pertanian atas ulayat kaum menurut adat Minangkabau tidak akan terlepas dari peran pemerintahan Nagari yang sudah ada sejak dahulu atau bisa disebut juga penyelesaian sengketa diluar pengadilan melalui jalur adat. Penyelesaian sengketa melalui jalur adat tidaklah serta merta diakui oleh Undang-Undang Kekuasaan Kehakiman yang berlaku pada saat sekarang ini, namun Undang-Undang Nomor 30 Tahun 1999 tentang Arbitrase dan Alternatif Penyelesaian Sengketa telah mengakomodir Penyelesaian Sengketa Secara Adat yaitu melewati Lembaga KAN (Kerapatan Adat Nagari).

Berdasarkan pasal 1 angka 10 dan alinea ke 9 (sembilan) dari penjelasan Umum Undang-undang No 30 Tahun 1999 tentang arbitrase dan alternatif penyelesaian sengketa dikatakan bahwa masyarakat dimungkinkan memakai alternatif lain dalam melakukan penyelesaian sengketa. Dalam lingkup hukum perdata penyelesaian suatu sengketa dapat diselesaikan melalui litigasi (pengadilan) dan non litigasi (luar pengadilan).

Di Indonesia pengakuan keberadaan masyarakat hukum adat dapat dilihat dari Undang-Undang Dasar Negara Republik Indonesia 1945 Pasal 18 B ayat (2) yang menyebutkan:

"Negara mengakui dan menghormati kesatuan-kesatuan masyarakat hukum adat beserta hak-hak tradisionalnya sepanjang masih hidup dan sesuai dengan perkembangan masyarakat dan prinsip negara kesatuan Republik Indonesia yang diatur dalam undangundang".

Dalam Undang-Undang Nomor 5 Tahun 1960 tentang Peraturan Dasar 
Pokok-Pokok Agraria Pasal 5 menyebutkan:

"Hukum agraria yang berlaku atas bumi, air dan ruang angkasa ialah hukum adat, sepanjang tidak bertentangan dengan kepentingan Nasional dan Negara, yang berdasarkan atas persatuan bangsa, dengan sosialisme Indonesia serta dengan peraturan-peraturan yang tercantum dalam Undang-Undang ini dan dengan peraturan perundangan lainnya, segala sesuatu dengan mengindahkan unsur-unsur yang bersandar pada hukum agama".

Dalam realita yang terjadi di lapangan justru sebaliknya, hak-hak masyarakat atas tanah ulayat justru tidak mendapat keadilan dari negara sebagai pemegang kekuasaan dan justru ini menyudutkan masyarakat hukum adat. Dapat diartikan hak-hak atas tanah berdasarkan hukum adat diakui sepanjang masih hidup dan tidak bertentangan dengan peraturan perundang-undangan dan hukum nasional lebih dominan penerapannya dibanding hukum adat yang berkaitan dengan tanah. Maka dari permasalahannya adalah: 1) Bagaimana pertimbangan majelis hakim terhadap penyelesaian sengketa gadai tanah pertanian atas ulayat kaum dalam putusan Peninjauan Kembali Nomor: 394 PK/PDT/2011?, 2) Bagaimana kedudukan pembeli tanah perkara dalam penyelesaian sengketa gadai tanah pertanian atas ulayat kaum setelah keluarnya putusan peninjauan kembali nomor 394 PK/PDT/2011?

\section{METODE PENELITIAN}

Penelitian ini berjenis penelitian hukum normatif (Yuridis Normative). penelitian ini difokuskan untuk mengkaji dan meneliti materi-materi hukum yang ada relevansinya dengan penelitian. Dalam hal ini yang menjadi sumber utama analisa dalam penelitian adalah peraturan perundang-undangan, serta berbagai literatur yang berkaitan dengan pokok permasalahan yang dibahas.

Dalam penyusunan Penelitian ini, dibutuhkan bahan atau data yang konkrit, yang berasal dari bahan kepustakaan. Pada penelitian hukum normatif, bahan pustaka merupakan data dasar yang dalam (ilmu) penelitian digolongkan sebagai data sekunder. Data sekunder tersebut mempunyai ruang lingkup yang sangat luas, sehingga meliputi surat-surat pribadi, buku-buku harian, buku-buku, sampai pada dokumen-dokumen resmi yang dikeluarkan oleh Pemerintah.

\section{HASIL DAN PEMBAHASAN}

1. Pertimbangan Majelis Hakim Terhadap Penyelesaian Sengketa Gadai Tanah Pertanian Atas Ulayat Kaum Dalam Putusan Peninjauan Kembali Nomor: 394 PK/PDT/2011

Dalam Putusan PK (Peninjauan Kembali) nomor 394 PK/PDT/2011 yang menjadi pokok perkara adalah harta pusako tinggi. Harta yang disengketakan merupakan sebidang tanah dan parak seluas $10.775 \mathrm{M}^{2}$ yang terletak di Sarang Unggeh, Dusun Pasir Kenagarian 
Aulia Ade Putra: Analisis Dikabulkannya Permohonan Peninjauan Kembali...

Singkarak, Kecamatan X Koto Singkarak, Kabupaten Solok.

Pada tahun 1926 terjadi pagang gadai antara Mamak Penggugat yang bernama Ayah Kea dengan Nenek Tergugat yang bernama Bugih dan yang menjadi objek gadai adalah sebahagian dari objek perkara yaitu berbentuk sawah dan sawah lain di luar objek perkara sebanyak ongkos naik haji ( \pm 100 Mas). Sementara objek perkara yang berupa parak dikuasai oleh Tergugat A secara melawan hukum tanpa hak dan pada tahun 2002 tanpa seizin dan sepengetahuan Penggugat. Penggugat dalam perkara ini adalah Rapius dan Gusnellidar Binti Syamsinar yang merupakan cucu dari Pemberi Gadai dahulunya dan yang menjadi Tergugat dalam perkara ini adalah Cucu Penerima Gadai dahulunya yang bernama Burhanuddin GLR Sutan Pangeran (Tergugat A) dan Asril Latif (Tergugat B1), Darlis Darwis S.E., M.M (Tergugat B2) dan Sudasril Darwis (Tergugat B3) selaku dari pembeli objek perkara atau pembeli objek gadai tersebut.

Pada tahun 1996/1997 berdasarkan saksi Penggugat yang bernama Latifah Harun, Burhanuddin GLR Sutan Pangeran pada tahun tersebut telah mengakui objek perkara tersebut dahulunya adalah tanah yang tergadai dan beliau meminta bukti kepada Penggugat (Gusnellidar), bahwa Penggugat adalah keturunan pemberi gadai dahulunya dengan meminta bukti ranji dan Burhanuddin GLR Sutan Pangeran juga menyatakan surat gadainya masih beliau pegang.

Pada tahun 2002 tanpa seizin Pemberi Gadai (Penggugat), Burhanuddin GLR Sutan Pangeran (Tergugat A) mengajukan permohonan Sertifikat Hak Milik atas objek perkara. Burhanuddin GLR Sutan Pangeran (Tergugat A) mengajukan permohonan penerbitan Sertifikat Hak Milik (SHM) atas objek perkara kepada Badan Pertanahan Nasional Kabupaten Solok. Sebelum Sertifikat Hak Milik terbit, atas sepengetahuan BPN Kabupaten Solok, objek perkara dijual oleh Burhanuddin GLR Sutan Pangeran kepada Asril Latif (Tergugat B1), Darlis Darwis S.E., M.M (Tergugat B2) dan Sudasril Darwis (Tergugat B3).

Berdasarkan jual beli tersebut, Tergugat C menerbitkan Sertifikat Hak Milik atas nama Asril Latif (Tergugat B1), Darlis Darwis S.E., M.M (Tergugat B2) dan Sudasril Darwis (Tergugat B3) dengan nomor Sertifikat Hak Milik C.57, Surat Ukur tertanggal 30 September 2002 seluas $10.775 \mathrm{M}^{2}$ dan sejak terbit Serttipikat Hak Milik tersebut objek perkara dikuasai oleh pembeli objek perkara tersebut. Perbuatan dari Burhanuddin GLR Sutan Pangeran (Tergugat A) mensertipikatkan dan menjual objek perkara kepada Tergugat B merupakan perbuatan melawan hukum dan tanpa hak dan Sertifikat Hak Milik Nomor C.57 yang diterbitkan oleh Badan Pertanahan Nasional Kabupaten Solok adalah cacat hukum dan batal demi hukum karena permohonan diajukan oleh 
orang yang tidak berhak yaitu Burhanuddin GLR Sutan Pangeran (Tergugat A).

Perbuatan pengalihan objek gadai/ objek perkara inilah yang menjadi dasar oleh Penggugat/Pemberi Gadai mengajukan gugatan ke Pengadilan Negeri Solok karena tanah yang dialihkan oleh Tergugat A kepada tergugat B adalah perbuatan melawan hukum karena objek gadai tersebut adalah milik kaum Penggugat yang sedang tergadai.

Sebelum persoalan ini diajukan ke Pengadilan Negeri Solok, Perkara ini telah diusahakan penyelesaian secara kekeluargaan baik melalui KAN Singkarak maupun melalui ke 2 (dua) wali nagari, Wali Nagari Singkarak dan Wali Nagari Tikalak, namun tidak ada penyelesaian atau titik temu.

Pada putusan Pengadilan Negeri Nomor 05/Pdt.G/2003/PN.SLK, Majelis Hakim mengabulkan sebagian gugatan penggugat, salah satu amar putusannya adalah menyatakan objek perkara adalah harta pusaka tinggi kaum penggugat dan menyatakan Sertifikat Hak Milik Nomor C 57 yang telah didaftarkan oleh Burhanuddin GLR Sutan Pangeran (Tergugat A) adalah cacat hukum dan tidak berkekuatan hukum, untuk perjanjian pagang gadai atas sebagian objek perkara yang berupa sawah putus dan berakhir. Dari amar putusan ini dapat dilihat objek perkara kembali dikuasai kepada pemberi gadai.

Dari putusan tingkat I (Pertama) tersebut, Tergugat mengajukan Banding ke Pengadilan Tinggi di Padang, namun berbeda halnya dengan Putusan Pengadilan Tinggi ini dengan nomor putusan 108/PDT/2004/PT.PDG tanggal 08 Oktober 2004, dimana majelis hakim berpendapat menolak gugatan penggugat seluruhnya dan menolak eksepsi dari Tergugat A dan Tergugat B.

Pada Putusan Kasasi Nomor: 1540 K/PDT/2005 tanggal 19 Juni 2006, dimana Majelis Hakim pada tingkat Mahkamah Agung ini berpendapat sama dengan Pengadilan Negeri. Majelis Hakim mengabulkan permohonan Kasasi dari Pemohon Kasasi yaitu, Rapius dan Gusnellidar binti Syamsinar dan membatalkan putusan Pengadilan Tinggi nomor 108/PDT/2004/PT.PDG.

Asril ST. Mangkuto yang merupakan ahli waris dari alm. Burhanuddin Sutan Pangeran, mengajukan permohonan peninjauan kembali terhadap putusan Kasasi Nomor: 1540 K/PDT/2005 tanggal 19 Juni 2006 yang telah Inkracht dan telah dilakukan eksekusi dan pada Putusan Peninjauan Kembali tersebut, Majelis Hakim Peninjauan Kembali memutuskan Asril ST. Mangkuto adalah pemilik objek perkara.

Dalam proses penyelesaian suatu perkara melalui pengadilan yakni para pihak yang bersengketa menghendaki adanya putusan yang adil dan dapat dilaksanakan. Berdasarkan putusan itu, ditentukan dengan pasti hak maupun hubungan hukum para pihak dengan objek yang disengketakan (Yahya Harahap, 2005: 797). 
Aulia Ade Putra: Analisis Dikabulkannya Permohonan Peninjauan Kembali...

Pada Peninjauan Kembali Tergugat A atau Pemohon Peninjauan Kembali, mengajukan 11 (sebelas) alasan-alasan Peninjauan Kembali sebagai berikut:

1. Putusan KAN secara legal formal hanyalah dijadikan pedoman dalam memutus perkara perdata, vide Yurisprudensi Mahkamah Agung tanggal 08 Juni 1977 Nomor 1128 K/ Sip/ 1977. Maksud dari pedoman tersebut bukan berarti putusan KAN tersebut yang menjadi dasar dan acuan dalam mengambil putusan oleh Pengadilan.

2. Menurut hukum adat di Minangkabau, KAN bukanlah berwenang memutus perkara tetapi adalah suatu lembaga yang salah satu fungsinya menyelesaikan persoalan adat dan jika dalam penyelesaiannya persoalan Adat tersebut ternyata tidak ada terdapat suatu perdamaian, maka KAN disarankan untuk melanjutkan persoalan tersebut ke Pengadilan.

3. Putusan Nagari Singkarak bukan putusan perkara Adat antara Penggugat dengan Tergugat tetapi adalah persidangan sepihak saja.

4. Tergugat mengajukan eksepsi diantaranya batas-batas objek perkara yang tidak sesuai antara yang tertera dalam surat gugatan dengan objek yang diperkarakan.

5. Dalam perkara ini Penggugat/Termohon Peninjauan Kembali ini tidak ada menampilkan seorangpun saksi sepadan.

6. Dalam mempertimbangkan harta pusaka tinggi kaum penggugat dan dalam mempertimbangkan harta perkara dahulunya digadaikan oleh ayah Kea kepada Bugih orang tikalak, Hakim Kasasi yang mengambil alih pertimbangan Hakim Pengadilan Negeri Solok berdasarkan kepada kesaksian dari saksi yang bukan saksi sepadan.

7. Pertimbangan Hakim Kasasi yang mengambil alih pertimbangan Pengadilan Negeri Solok halaman 64 dan halaman 65 yang pada pokoknya disebabkan karena para saksi Tergugat A/saksi Pemohon Peninjauan Kembali tidak bisa menjelaskan penguasaan tanah perkara sebelum tahun 1926 maka kesaksiannya harusnya ditolak.

8. Tidak seorangpun yang bisa menghubungkan dengan ranji orang yang bernama Ayah Kea, karena nama Kea hanyalah ditemukan dalam Ranji Penggugat/Termohon Peninjauan Kembali.

9. Majelis Hakim Kasasi tidak sedikitpun mempertimbangkan mana sawah yang tergadai dan mana pula tanah yang dikuasai secara tanpa hak oleh Tergugat A.

10. Jika tanah sebelah ke utara dan timur dari tanah yang pemohon peninjauan kembali jual kepada Tergugat B dikuasai oleh Jamin dan Andi Suhairi, maka orang tersebut haruslah di gugat dalam perkara in casue.

11. Majelis Hakim Peninjauan Kembali tidak mempertimbangkan sedikitpun itikad baik dari pada si pembeli tanah perkara (Tergugat B). 
Dari 11 (sebelas) alasan diajukan permohonan peninjauan kembali oleh Tergugat A tersebut diatas, majelis hakim Peninjauan Kembali berpendapat bahwa alasan tersebut dapat dibenarkan oleh karena dalam putusan yang dimohonkan Peninjauan Kembali terdapat khilafan hakim atau suatu kekeliruan yang nyata dari hakim dengan pertimbangan sebagai berikut:

1. Bahwa KAN (Kerapatan Adat Nagari) tidak berwenang memutus kepemilikan tanah sengketa.

2. Bahwa Tergugat $\mathrm{B}$ adalah pembeli beritikad baik harus dilindungi dan ia sudah menguasai objek sengketa selama kurang lebih 77 tahun sehingga Tergugat B sebagai pembeli yang beritikad baik adalah pemilik objek sengketa.

3. Bahwa putusan KAN tidak dapat dipakai sebagai acuan karena yang bersengketa adalah dari Kenagarian yang berbeda yaitu Penggugat/ Rapius dari Kenagarian Singkarak sedang Tergugat A dan B dari Kenagarian Tikalak.

Penyelesaian sengketa gadai tanah pertanian atas ulayat kaum menurut adat Minangkabau tidak akan terlepas dari peran pemerintahan Nagari yang sudah ada sejak dahulu atau bisa disebut juga penyelesaian sengketa diluar pengadilan melalui jalur adat. Penyelesaian sengketa melalui jalur adat tidaklah serta-merta diakui oleh Undang-Undang Kekuasaan Kehakiman yang berlaku pada saat sekarang ini, namun Undang-Undang Nomor 30 Tahun 1999 tentang Arbitrase dan Alternatif Penyelesaian Sengketa telah mengakomodir Penyelesaian Sengketa Secara Adat yaitu melewati Lembaga KAN (Kerapatan Adat Nagari).

Penyelesaian silang sangketo (Persengketaan) antara masyarakat komunal di Minangkabau diperlukan suatu lembaga adat yang disebut Kerapatan Adat Nagari, dimana penyelesaian melalui lembaga KAN merupakan penyelesaian sengketa non litigasi (diluar pengadilan) yang dapat melalui mediasi, negosiasi, konsultasi dan konsiliasi. Terkadang banyak sengketa yang dibawa ke jalur litigasi (pengadilan) untuk menyelesaikan perkara tersebut.

\section{Kedudukan Pembeli Tanah Perkara Dalam Penyelesaian Sengketa Gadai Tanah Pertanian Atas Ulayat Kaum (Dalam Putusan Peninjauan Kembali Nomor 394 PK/PDT/ 2011)}

Di dalam Putusan Peninjauan Kembali Nomor 394 PK/PDT/2011, Mahkamah Agung berpendapat bahwa alasan tersebut dapat dibenarkan oleh karena dalam putusan yang dimohonkan Peninjauan Kembali terdapat khilafan hakim atau suatu kekeliruan yang nyata dari hakim dengan pertimbangan sebagai berikut:

a. Bahwa KAN (Kerapatan Adat Nagari) tidak berwenang memutus kepemilikan tanah sengketa.

b. Bahwa Tergugat B adalah pembeli beritikad baik harus dilindungi dan ia sudah menguasai objek sengketa selama kurang lebih 77 tahun 
Aulia Ade Putra: Analisis Dikabulkannya Permohonan Peninjauan Kembali...

sehingga Tergugat B sebagai pembeli yang beritikad baik adalah pemilik objek sengketa.

c. Bahwa putusan KAN tidak dapat dipakai sebagai acuan karena yang bersengketa adalah dari Kenagarian yang berbeda yaitu Penggugat/ Rapius dari Kenagarian Singkarak sedang Tergugat A dan B dari Kenagarian Tikalak.

Berdasarkan hal-hal yang disebutkan diatas, Mahkamah Agung berpendapat tidak perlu mempertimbangkan alasanalasan Peninjauan Kembali lainnya karena menurut Mahkamah Agung terdapat cukup alasan untuk mengabulkan permohonan Peninjauan Kembali yang diajukan oleh Pemohon Peninjauan Kembali. Asril ST Mangkuto adalah ahli waris dari almarhum. Burhanuddin Sutan Pangeran dan membatalkan putusan Mahkamah Agung Nomor 1540 K/ Pdt/ 2005 tanggal 19 Juni 2006 serta Mahkamah Agung akan mengadili kembali perkara ini. Mahkamah Agung mengeluarkan amar putusan sebagai berikut:

a. Mengabulkan permohonan Peninjauan Kembali dari para Pemohon Peninjauan Kembali Asril ST. Mangkuto adalah ahli waris dari almarhum. Burhanuddin Sutan Pangeran tersebut.

b. Membatalkan putusan Mahkamah Agung Nomor: 1540 K/Pdt/2005 tanggal 19 Juni 2006.

c. Dalam Mengadili Kembali, Mahkamah Agung menerima permohonan banding dari Tergugat A dan Tergugat B/Pembanding dan Membatalkan putusan Pengadilan Negeri Solok tanggal 20 April 2004 Nomor: 05/Pdt.G/2003/PN.SLK.

d. Dan dengan mengadili sendiri dalam eksepsi, menolak eksepsi dari Tergugat A dan Tergugat B seluruhnya

e. Dalam Pokok Perkara, menolak gugatan Penggugat untuk seluruhnya.

f. Bahwa karena Termohon Peninjauan Kembali adalah pihak yang kalah, maka dihukum untuk membayar biaya perkara dalam semua tingkat peradilan dan dalam Peninjauan Kembali.

Amar putusan Mahkamah Agung menyiratkan bahwa, dikabulkannya Peninjauan Kembali Pemohon, keadaan ini memberikan dampak bahwa tanah seluas 10.777 M2 akan menjadi milik Tergugat B dengan pertimbangan hakim, Tergugat $\mathrm{B}$ pembeli beritikad baik harus dilindungi dan ia sudah menguasai objek sengketa selama kurang lebih 77 tahun. Pertimbangan KAN dan bukti-bukti pada tingkat Pengadilan Negeri dikesampingkan oleh Majelis Hakim Peninjauan Kembali ini, tentu ini menjadi masalah di tengah masyarakat Minangkabau apabila terdapat permasalahan yang sama, karena Mahkamah Agung tidak melihat nilainilai adat yang ada di tengah masyarakat Minangkabau antara tanah dengan pemiliknya, khususnya dalam ranah gadai tanah pertanian atas ulayat kaum ini.

Di Minangkabau ada rasa malu pada saat gadai tidak ditebus, apalagi kalau 
sampai objek gadai di eksekusi. Hal ini juga sejalan dengan pepatah adat Minangkabau "utang lansai dek babayia, ketek utang dek angsuran" (utang wajib dibayar dan akan bertambah kecil kalau diangsur membayar). Rasa malu yang diperkuat oleh pepatah adat "adat basandi syarak, syarak basandi kitabullah, syarak mangato adat mamakai" (adat berdasarkan agama dan agama berdasarkan kitab Allah SWT), falsafah ini akan selalu menjadi pegangan oleh masyarakat hukum adat. Gadai harus ditebus karena di samping malu, maka agama juga menjadi pedoman adat dimana agama tidak menghalalkan utang yang tidak dibayar.

Tanah adat tentu merupakan milik bersama masyarakat hukum adat suatu kaum, dimana sifat gotong royong dan saling peduli masih dijunjung tinggi tentu saja tidak akan membiarkan tanah adat mereka beralih karena gadai yang tidak ditebus. Hal ini bisa dilihat dari pepatah adat Minangkabau "Limbago urang badunsanak, Hanyuik samo dipinteh; Tabanam samo disalami, Tarandam samo basah; Tahampai samo kariang, Hilang samo dicari; Luko samo manyiuik, Sakik samo maaduah, Tuah samo sakato" (lembaga orang berkeluarga, Hanyut sama ditelusuri, terbenam sama diselami, terendam sama basah, dijemur sama kering, hilang sama dicari, luka sama meniup, sakit sama mengaduh, tuah sama sekata).

Pada prinsipnya gadai tanah pertanian secara adat di Minangkabau dikonstruksikan seperti bentuk "Jual beli dengan hak membeli kembali”. Gadai tanah pertanian di Minangkabau lebih kepada faktor sosial yang lebih berperan. Nilai gadai di Minangkabau sebagaian besar sudah mendekati nilai jual tanah pertanian tersebut dan diantaranya sudah diatas harga jual tanah, hal ini tidak terlepas dari kebiasaan "tukuak tambah" (pemberi gadai meminta tambahan nilai gadai kepada pemegang gadai) dan ini bisa dilakukan berkali-kali. Apabila sipemegang gadai tidak sanggup menambah nilai gadai sesuai dengan keinginan pemberi gadai, maka biasanya pemberi gadai akan melakukan alih gadai kepada pihak lain, hingga bisa sampai melampaui nilai jual tanah objek gadai tersebut.

Ada beberapa syarat dalam gadai tanah yang harus dipenuhi oleh penggadai dan pemegang gadai yaitu:

a. Gadai baru sah apabila disetujui oleh segenap ahli waris, satu orang saja tidak menyetujui gadai, maka gadai menjadi batal demi hukum;

b. Gadai tidak ada kadaluarsanya;

c. Pihak penggadai punya hak pertama untuk menggarap tanah gadaian, kecuali jika dia mau menyerahkan garapan pada orang lain;

d. Pemegang gadai tidak boleh menggadaikan lagi tanah yang dipegangnya pada orang lain tanpa seizin pemilik tanah. Sekarang karena ada pengaruh hukum barat pemegang gadai boleh menggadaikannya lagi (herverpanding) pada pihak lain;

e. Selama gadai berjalan pemilik tanah gadai boleh minta tambahan uang 
Aulia Ade Putra: Analisis Dikabulkannya Permohonan Peninjauan Kembali...

gadai pada pemegang gadai tapi pembayaran penebusannya nanti mesti sekaligus.

Di Minangkabau gadai itu haruslah ditebus sebagaimana pepatah minang "Gadai ditabuih, jua dipalalui" (gadai harus ditebus, jual dibiarkan lepas). Gadai di Minangkabau selalu ditebusi, tanpa terikat pada suatu jangka waktu tertentu. Hal ini sudah berjalan dari dahulunya terkait dengan gadai tanah pertanian, dimana pemberi gadai meminta atau mengambil kembali tanah yang digadaikannya selalu dengan tebusan, walau sebagian masyarakat sudah mengetahui ketentuan Pasal 7 ayat (2) Undang-Undang Nomor 56 Prp Tahun 1960, dimana setelah jangka waktu 7 tahun tanah pertanian yang digadaikan kembali ke pemilik tanpa tebusan. Pada prakteknya dari dahulu sampai dengan sekarang ini, masyarakat tidak berani atau tidak punya keinginan untuk menerapkan ketentuan pengembalian gadai tanpa tebusan ini.

Ketentuan hukum adat Minangkabau "Gadai ditabuih, jua dipalalui" (gadai harus ditebus, jual dibiarkan lepas) masih mengakar kuat, malu bagi Masyarakat hukum adat Minangkabau mengambil atau meminta kembali tanah yang mereka gadaikan tanpa membayar uang (nilai) gadai yang sudah mereka terima dari penerima gadai. Ketentuan ini merupakan norma yang sudah dipedomani masyarakat Minangkabau sejak zaman dahulu dan tidak berkeinginan untuk merubahnya.
Selain dengan pagang gadai ada juga dikenal istilah pagang susuik/ampang, kalau pagang gadai harus ditebus namun pagang susuik menganut pola yang berbeda. Pagang susuik diperhitungkan dari hasil yang diterima oleh pemegang gadai/ penerima gadai, dimana hasil tanah pertanian berupa sawah dianggap sekaligus sebagai cicilan atas pinjaman pemilik tanah atau pemberi gadai, namun hal ini biasanya untuk pinjaman kecil dan jangka waktu yang tidak terlalu lama.

Terhadap gadai tanah pertanian secara adat tidaklah diatur secara khusus di dalam peraturan perundang-undangan yang berlaku di Indonesia. Di salah satu Pasal dalam Undang-Undang Nomor 56 Prp Tahun 1960 tentang Penetapan Luas Tanah Pertanian yaitu dalam pasal 7 ayat (2) menyebutkan bahwa gadai tanah pertanian adalah hubungan seseorang dengan tanah kepunyaan orang lain yang mempunyai hutang kepadanya, selama utang tersebut belum dibayar lunas, maka tanah tersebut tetap berada dalam penguasaan yang meminjamkan uang (pemegang gadai). Namun apabila telah lewat jangka waktu 7 (tujuh) tahun maka pengembalian tanah tersebut tanpa uang tebusan.

Undang-undang ini hanya mengatur tentang pengembalian tanpa tebusan setelah jangka waktu gadai 7 tahun tersebut saja, tanpa mengatur hal-hal lain tentang gadai tanah pertanian ini. Semenjak diundangkan hingga saat ini yaitu sudah 57 tahun Undang-Undang Nomor 56 Tahun 1960 ini secara legalitas formal masih tetap berlaku dan belum 
pernah dirubah ataupun dicabut, namun dalam pelaksanaannya terutama di Minangkabau khususnya ketentuan Pasal 7 ayat (2) nyaris tidaklah punya kekuatan mengikat. Berdasarkan banyak penelitian tentang gadai tanah pertanian di Minangkabau dapat disimpulkan, masyarakat hukum adat Minangkabau sudah mengetahui ketentuan ini, namun dalam pelaksanaannya masyarakat masih tunduk dan mentaati ketentuan hukum adat ketimbang ketentuan perundangundangan nasional ini.

Pendapat hakim pada peninjauan kembali ini sangatlah keliru, tidak berdasar dan jauh dari keadilan, karena pada Putusan Pengadilan Negeri dalam pokok perkara menyatakan "Perbuatan tergugat A mengajukan permohonan sertifikat hak milik atas harta sengketa/ objek perkara adalah perbuatan yang melawan hukum dan menyatakan jual beli objek perkara antara Tergugat A dan Tergugat B adalah cacat hukum dan karenanya batal demi hukum dan menyatakan sertifikat hak milik nomor $\mathrm{C}$ 57 surat ukur 30 September tahun 2002 atas nama Tergugat $\mathrm{B}$ yang diterbitkan oleh Tergugat $\mathrm{C}$ adalah cacat hukum dan tidak berkekuatan hukum.

Putusan Pengadilan Negeri tersebut sudah diperkuat kembali dengan Putusan Mahkamah Agung RI Nomor 1540 K/PDT/2005 tanggal 19 Juni 2006. Apabila putusan PK tersebut dikaitkan dengan ketentuan hukum gadai tanah pertanian atas ulayat kaum maupun Undang-Undang Nomor 56 Prp Tahun 1960 tentang penetapan luas tanah pertanian, maka kedua aturan hukum tersebut tidak bisa melandasi dari keputusan tersebut oleh sebab itu penulis berpendapat, putusan tersebut tidak berdasarkan hukum karana gadai di Minangkabau harus ditebus dan tidak memiliki jangka waktu dan bila yang dipakai adalah ketentuan Pasal 7 ayat (2) Undang-Undang Nomor 56 Prp Tahun 1960, dimana setelah jangka waktu 7 tahun tanah pertanian yang digadaikan kembali ke pemilik tanpa tebusan.

Berdasarkan keterangan saksi-saksi yang dihadirkan Penggugat pada pemeriksaan di Persidangan di Pengadilan Negeri, Tergugat A telah terbukti mengakui bahwa objek sengketa adalah tanah gadai yang ia dapat secara turun temurun dan Tergugat A juga meminta Penggugat segera mengurus surat-surat ranji untuk membuktikan bahwa Penggugat adalah keturunan pemberi gadai dahulunya.

Menurut Ahmad Ali MD mengatakan bahwa, "keadilan sebuah putusan hukum yang dijatuhkan oleh hakim terhadap pencari keadilan haruslah diambil berdasarkan kebenaran substantif, memberikan sesuatu kepada yang berhak menerimanya. Sebuah Putusan Hakim harus mengandung beberapa aspek (Ahmad Ali MD, 2012: 132):

a. Putusan hakim merupakan gambaran proses kehidupan sosial sebagai bagian dari proses kontrol sosial;

b. Putusan Hakim merupakan penjelmaan dari hukum yang berlaku dan pada intinya berguna untuk setiap 
Aulia Ade Putra: Analisis Dikabulkannya Permohonan Peninjauan Kembali...

orang maupun kelompok dan juga negara;

c. Putusan Hakim merupakan gambaran keseimbangan antara ketentuan hukum dengan kenyataan di lapangan;

d. Putusan Hakim merupakan gambaran kesadaran yang ideal antara hukum dan perubahan sosial;

e. Putusan Hakim harus bermanfaat bagi setiap orang yang berperkara;

f. Putusan Hakim merupakan tidak menimbulkan konflik baru bagi para pihak yang berperkara dan masyarakat.

Mochtar Kusumaatmadja juga menyatakan dalam mencapai ketertiban dalam masyarakat diperlukan adanya kepastian hukum, namun antara kepastian hukum selalu terjadi benturan antara lain :

1. Kepastian hukum dengan kemanfaatan

2. Keadilan dengan kepastian hukum,

3. Keadilan dengan kemanfaatan.

Hukum harus dapat dilihat dalam Perundang-undangan, hal ini didasarkan pada aliran Positivisme hukum, dalam aliran ini hukum tertulis diatas segalanya dengan kata lain hukum tertulis merupakan suatu keharusan, dengan inilah ketentuan hukum dapat diidentifikasi, sehingga aliran ini beranggapan bahwa tidak ada norma hukum di luar hukum positif (Muhammad Erwin, 2013: 155).

Dari sisi kepastian hukum adanya putusan yang saling tidak sama atau bertentangan untuk kasus yang sama tentu juga menjadi persoalan, di satu sisi keberadaan Hukum Adat diakui oleh Konstitusi dan UUPA, namun pada sisi lain dalam menyelesaikan sengketa yang muncul berkaitan dengan tanah adat yang masih tunduk pada hukum adat justru putusan pengadilan tidak memberikan kepastian hukum.

Menurut Gustav Radbruch, kepastian hukum dalam hukum tercapai apabila hukum tersebut sebanyak-banyaknya ada dalam undang-undang. Mochtar Kusumaatmadja juga menyatakan bahwa untuk mencapai ketertiban diusahakan adanya kepastian hukum dalam pergaulan manusia di masyarakat. Sebagaimana diketahui bahwa seringkali antara kepastian hukum terjadi benturan dengan kemanfaatan, atau antara keadilan dengan kepastian hukum, antara keadilan terjadi benturan dengan kemanfaatan (Mochtar Kusumaatmadja, 2000: 3).

Penegakan Hukum tidak terlepas dari unsur keadilan, unsur kepastian hukum dan unsur kemanfaatan. Dalam menegakkan tidak bisa menjalankan salah satu dari 3 (tiga) unsur diatas, apabila salah satu unsur ditegakkan dan yang lain tidak, maka akan ada unsur-unsur lain yang akan dikorbankan. Misal unsur keadilan diutamakan, maka unsur kepastian hukum dan kemanfaatan akan menjadi korban dan inilah yang menyebabkan unsur ini tidak dapat dipisahkan namun saling bertentangan satu dengan yang lainnya.

Jadi dalam melaksanakan ketiga unsur diatas yang tujuan akhirnya adalah penegakan hukum harus ada kesepakatan 
antara ketiga unsur tersebut, namun pada prakteknya, merupakan pekerjaan yang tidak mudah menyeimbangkan antara ketiga unsur tersebut. Tidak boleh memisah ketiganya, akan tetapi jika ada pertentangan di antara ketiga, harus didahulukan mana yang akan memiliki manfaat besar bagi masyarakat.

\section{SIMPULAN}

1. Pada putusan Peninjauan Kembali tersebut majelis hakim menyebutkan bahwa "terdapat khilafan hakim atau suatu kekeliruan yang nyata dari hakim”, kekhilafan yang dimaksud disini adalah pertama, KAN (Kerapatan Adat Nagari) tidak berwenang memutus kepemilikan tanah sengketa dan keputusan KAN tidak dapat dipakai sebagai acuan, karena yang bersengketa adalah kenagarian yang berbeda, alasan inilah yang menjadikan Peninjauan Kembali dari pemohon diterima oleh Majelis Hakim. Dari hal tersebut diatas Penulis melihat bahwa pada pemeriksaan di Tingkat Pengadilan Negeri, Majelis Hakim yang memeriksa perkara mempertimbangkan keputusan KAN karena putusan Kerapatan Adat Nagari dapat dijadikan alat bukti di dalam proses persidangan dan menurut hemat penulis, keterangan KAN pada pemeriksaan di tingkat Pengadilan Negeri sudah relevan. Untuk kedudukan KAN sebagai alat bukti dalam proses hukum acara perdata khusunya sengketa tanah ulayat kaum, sudah banyak dilakukan penelitian di beberapa Pengadilan Negeri di Sumatera Barat. Karena KAN lah yang bersinggungan langsung dengan masyarakat hukum adat di Nagari tersebut. Mengingat perkara ini adalah perkara yang berkaitan dengan tanah ulayat. Tanah ulayat adalah masalah yang sangat sensitif bagi masyarakat hukum adat. Bisa dibayangkan apa yang akan terjadi jika masyarakat suatu kaum kehilangan hak atas tanah ulayatnya. Berdasarkan Pasal 73 ayat 1 UndangUndang Nomor 5 Tahun 2004 tentang Mahkamah Agung, memberikan wewenang kepada Mahkamah Agung, dalam hal ini Majelis Peninjauan Kembali untuk memerintahkan pemeriksaan tambahan dan majelis hakim bisa meminta keterangan kembali kepada pengadilan tingkat pertama untuk memeriksa kembali mengenai kedudukan KAN. Berdasarkan Pasal 18 B Undang-Undang Dasar 1945, Negara masih mengakui kesatuan masyarakat hukum adat dan Berdasarkan Pasal 12 ayat (1) Peraturan Daerah Propinsi Sumatera Barat Nomor: 16 Tahun 2008 tentang Tanah Ulayat Dan Pemanfaatannya “ sengketa tanah ulayat di Nagari diselesaikan oleh KAN menurut ketentuan sepanjang adat yang berlaku "Bajanjang Naiak Batanggo Turun" dan diusahakan dengan jalan perdamaian melalui musyawarah dan mufakat dalam bentuk keputusan perdamaian. Khusus untuk sengketa tanah ulayat antar Nagari juga telah 
Aulia Ade Putra: Analisis Dikabulkannya Permohonan Peninjauan Kembali...

diatur dalam peraturan ini, dimana diselesaikan oleh KAN antar Nagari yang bersengketa. Jadi majelis hakim peninjauan kembali harusnya lebih menggali nilai-nilai hukum yang hidup di tengah masyarakat minangkabau yang sudah berlangsung sebelum Indonesia merdeka.

2. Pendapat hakim pada Peninjauan Kembali ini sangatlah keliru, tidak berdasar dan jauh dari keadilan, karena pada Putusan Pengadilan Negeri dalam pokok perkara menyatakan "Perbuatan tergugat A mengajukan permohonan sertifikat hak milik atas harta sengketa/ objek perkara adalah perbuatan yang melawan hukum dan menyatakan jual beli objek perkara antara Tergugat A dan Tergugat $\mathrm{B}$ adalah cacat hukum dan karenanya batal demi hukum dan menyatakan sertifikat hak milik nomor C 57 surat ukur 30 September tahun 2002 atas nama Tergugat B yang diterbitkan oleh Tergugat $\mathrm{C}$ adalah cacat hukum dan tidak berkekuatan hukum. Putusan Pengadilan Negeri tersebut sudah diperkuat kembali dengan Putusan Mahkamah Agung RI Nomor 1540 K/ PDT/ 2005 tanggal 19 Juni 2006. Apabila putusan PK tersebut dikaitkan dengan ketentuan hukum gadai tanah pertanian atas ulayat kaum maupun Undang-Undang Nomor 56 Prp Tahun 1960 tentang penetapan luas tanah pertanian, maka kedua aturan hukum tersebut tidak bisa melandasi dari keputusan tersebut oleh sebab itu penulis berpendapat, putusan tersebut tidak berdasarkan hukum karna gadai di Minangkabau harus ditebus dan tidak memiliki jangka waktu dan bila yang dipakai adalah ketentuan Pasal 7 ayat (2) Undang-Undang Nomor 56 Prp Tahun 1960, dimana setelah jangka waktu 7 tahun tanah pertanian yang digadaikan kembali ke pemilik tanpa tebusan.

\section{SARAN}

1. Penyelesaian sengketa gadai tanah pertanian atas ulayat kaum ini hendaknya jangan sampai masuk dalam ranah Pengadilan, di samping memakan biaya yang besar penyelesaian perkara melalui jalur ini memakan waktu yang lama. Baiknya penyelesaian permasalahan gadai ini mendapat titik temu/ kesepakatan melalui cara kekeluargaan atau melaui lembaga adat. Dan untuk mencapai perdamaian hendaknya para pihak saling jujur dalam menyelesaikan masalah ini. Terhadap ketentuan Undang-Undang nomor 56 Prp Tahun 1960 perihal pengembalian gadai tanah pertanian setelah lewat jangka 7 tahun tanpa tebusan agar dilakukan perubahan atau pembaharuan, karena nilai-nilai yang hidup di masyarakat Minangkabau gadai harus ditebus dan jual dibiarkan lepas.

2. Proses pemeriksaan PK seharusnya memberikan tugas bagi hakim agung untuk turun langsung ke tengah masyarakat, agar hakim lebih peka 
terhadap perasaan hukum dan rasa keadilan yang berguna dalam masyarakat dan Penggugat hendaknya kembali menelusuri asal harta pusaka tingginya. Sehingga tidak ada lagi harta pusaka tinggi yang berada dalam penguasaan orang lain yang dalam hal ini merupakan tugas dari seorang mamak kepala waris dan apabila terdapat harta tanah kaum yang masih tergadai, maka segera dilakukan penyelesaian dengan jalan penebusan. Mamak Kepala Waris yang bertugas menjaga keutuhan kaum dan menjaga tanah pusako tinggi hendaknya melaksanakan tugas dan tanggung jawabnya untuk menjaga tanah pusako tinggi menurut ketentuan adat yang berlaku sehingga dikemudian hari tidak terdapat lagi sengketa yang demikian.

\section{DAFTAR PUSTAKA}

\section{Buku-Buku:}

Ahmad Ali MD, 2012, Keadilan Hukum Bagi Orang Miskin, Jurnal Mimbar Hukum dan Keadilan, Edisi I, Jogyakarta.

Aermadepa, 2018, Gadai Tanah Pertanian Secara Adat Sebagai Jaminan Utang Pada Masyarakat Hukum Adat Di Sumatera Barat, Disertasi, Universitas Andalas, Padang.

Bambang Sunggono, 2010, Metodologi Penelitian Hukum, Rajawali Pers, Jakarta.

Boedi Harsono, 2007, Hukum Agraria Indonesia, Djambatan, Jakarta.
Dominikus Rato, 2016, Hukum Benda dan Harta Kekayaan Adat, LaksBang PRESSindo, Yogyakarta.

Erwin, 2006, Tanah Komunal Memudarnya Solidaritas Sosial Pada Masyarakat Matrilinial Minangkabau, Andalas University Press, Padang.

Gustav Radbruch dalam Shidarta, 2010, Putusan Hakim: Antara Keadilan, Kepastian Hukum, dan Kemanfaatan, Reformasi Peradilan dan Tanggung Jawab Negara, Komisi Yudisial, Jakarta.

Iman Sudiyat, 2012, Hukum Adat Sketsa Asas, Liberty, Yogyakarta.

Kurnia Warman, 2009, Pengaturan Sumberdaya Agraria Pada Era Desentralisasi Pemerintahan di Sumatera Barat (Interaksi Hukum Adat dan Hukum Negara Dalam Perspektif Keanekaragaman Dalam Kesatuan Hukum), Disertasi, Universitas Gadjah Mada, Yogyakarta.

Muhammad Erwin, 2013, Filsafat Hukum Refleksi Kritis Terhadap Hukum, PT. Raja Grafindo Persada, Jakarta.

Muhammad Yamin, 2004, Gadai Tanah Sebagai Lembaga Pembiayaan Rakyat Kecil, Pustaka Bangsa Press, Medan..

Musyair Zainuddin, 2014, Ranah Minang dan Lingkungan Hidup, Ombak, Yogyakarta.

Mochtar Kusumaatmadja, 2000, Pengantar Ilmu Hukum, Suatu Pengenalan Pertama Ruang Lingkup Berlakunya Ilmu Hukum, Alumni, Bandung. 
Aulia Ade Putra: Analisis Dikabulkannya Permohonan Peninjauan Kembali...

Suparjo Sujadi, 2004, Analisis dan Prediksi Permasalahan Pertanahan di Masa Mendatang-Hukum dan Pembangunan 4, Jakarta.

Takdir Rahmadi, 2010, Mediasi Penyelesaian Sengketa Melalui Pendekatan Mufakat, Rajawali Pers, Jakarta.

Yahya Harahap, 2005, Hukum Acara Perdata, Sinar Grafika, Jakarta.

\section{Peraturan Perundang-Undangan :}

Kitab Undang-Undang Hukum Perdata (KUHPerdata).

Undang-Undang Nomor 5 Tahun 1960 Tentang Peraturan Dasar PokokPokok Agraria.
Undang-Undang Nomor 4 Tahun 1996 Tentang Hak Tanggungan Atas Tanah Beserta Benda-Benda Yang Berkaitan Dengan Tanah.

Undang-Undang No. 56 Prp Tahun 1960 Tentang Penetapan Luas Tanah Pertanian.

Peraturan Mahkamah Agung No.1 Tahun 2008 Tentang Mediasi.

Peraturan Daerah Propinsi Sumatera Barat Nomor: 16 Tahun 2008 Tentang Tanah Ulayat Dan Pemanfaatannya. 